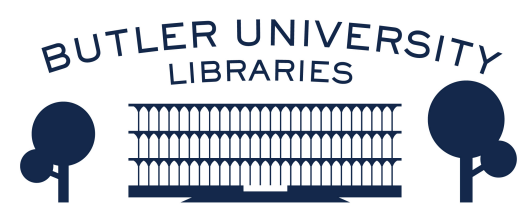

Journal of Hindu-Christian Studies

Volume 25

Article 8

November 2012

\title{
'Where did you hide?' Locating the divine in the Cántico espiritual and Rāsa Līlā
}

Gloria M. Hernández

Follow this and additional works at: https://digitalcommons.butler.edu/jhcs

Part of the Religion Commons

\section{Recommended Citation}

Hernández, Gloria M. (2012) "'Where did you hide?' Locating the divine in the Cántico espiritual and Rāsa Līlā," Journal of Hindu-Christian Studies: Vol. 25, Article 8.

Available at: https://doi.org/10.7825/2164-6279.1514

The Journal of Hindu-Christian Studies is a publication of the Society for Hindu-Christian Studies. The digital version is made available by Digital Commons @ Butler University. For questions about the Journal or the Society, please contact cbauman@butler.edu. For more information about Digital Commons @ Butler University, please contact digitalscholarship@butler.edu. 


\title{
'Where did you hide?' Locating the divine in the Cántico espiritual and Rāsa Lìlā
}

\author{
Gloria Maité Hernández \\ West Chester University
}

¿Adónde te escondiste? Where did you hide? Cántico espiritual

kvāsi kvāsi mahābhūja Where are you, the one with big arms? ${ }^{1}$

Rāsa Lìlā

THE poetical and theological dynamics of apparent absence, which kindle the desire for the always-elusive presence of God, are shared by the Sanskrit Rāsa Lìlā and the Spanish Cántico espiritual. Although these Hindu and Christian mystical works of literature are not historically or philologically related, they converse in poetical and theological terms, revealing aspects that are not so obvious when they are read alone. ${ }^{2}$ Here I am bringing these texts together because they first have as David Damrosch says, resonated in the mind of a reader "where works meet and interact in ways that may have little to do with cultural and historical proximity" (298). Having had a longstanding interaction with the writings and the teachings of Juan de la Cruz, when I first encountered Rāsa Lìlā I was overtaken by the resonant modes in which these works ask for the whereabouts of the divine lover, the Amado (male lover) in the Cántico, and Kṛṣna in Rāsa Lìla. This first encounter took me on a scholarly and personal journey where I learned to relish the texts by themselves and through their interaction.

The inquiry for God's location in Rāsa Lìla and the Cántico, as in all mystical literature, cannot be addressed from an exclusively literary or exclusively theological viewpoint. ${ }^{3}$ Accordingly, this comparison relies upon a close reading of passages previously selected that leads into a dialogue between poetry and theology about how both works perform, rather than describe, the search for the divine's location. ${ }^{4}$ With this, I assume a perspective of comparison that arrives at theological questions from a literary analysis, and does not exclude either literature or theology. I conceive these close comparative readings as if two transparencies were superimposed and made visible by the light of an overhead projector that allows, in turn, the reader to focus on specific moments where the poetical images overlap and become intensified, and also on areas where they depart from each other. Following the superimposition of the texts, the reader also finds herself overlapped by the profusion of comparative possibilities, far larger than what can be addressed here. I welcome this unsettling abundance, like Francis Clooney has taught us, as a sign of the

Gloria Maité Hernández is an Assistant Professor at the Department of Languages and Cultures of West Chester University. She completed her PhD at Emory University as an American Dissertation Fellow of the Association of American University Women (2011). Her research focuses on Iberian Medieval and Early Modern literature, particularly mystical literature, and Sanskrit Vaișnava literature, specifically the Bhāgavata Purāna. Her publications include "Mirando a Dios: El Cántico espiritual y Rāsa Lìlā," Hispanic Horizons. Jawaharlal Nehru University (2012), and "The Conde Lucanor and Panchatantra: Comparison, Power and Translation," Literature Compass. Special Issue: The Global Middle Ages. Forthcoming 2013. Currently she is working on the manuscript of her book Absence, Presence, and Divine Vision, a literary and theological comparison between the Spanish text and commentary of the Cántico espiritual by Juan de la Cruz and the Sanskrit text Rāsa Lìlā (The dance of divine love), along with Srīdhara Svāmi's commentary. 
textual proliferation born from the textual conversation. $^{5}$ The sharing of love between Kṛṣna and the gopis in the bhakti of Rāsa Lìlā, as the tasting of the living God in the Cántico, is a mixture of the divine's sweetness and the bitterness of his unexpected departures. Together, the texts produce a new taste that is even more intense, sometimes bizarre, at once subduing and uncertain. I attempt a path of comparison that allows appreciating such tasteful variety while focusing on the question of God's whereabouts.

In the Cántico espiritual, the voice of the Amada-female beloved- cries out for the absence of her Amado. Inspired by the Song of Songs, the Cántico and its commentary were composed in the sixteenth century by Juan de la Cruz. ${ }^{6}$ The poem begins the moment after the disappearance of the divine lover, and thereafter the Amada is engaged exclusively in the search for him. At times she encounters her lover, but afterwards he again departs, prompting a new search. In his commentaries Juan de la Cruz qualifies his work as teología mistica, using the same connotations that Dionysius the Areopagite had used in the Greek theologia mystike to evoke a sense of mutual sharing, loving, and tasting between the human and the divine. Meant to evoke the experience of "tasting the living God," the verses of the Cántico describe the Amada drinking the "savory science of mystical theology" in the interior wine cellar of her lover, while reposing her head on his chest (26.5). ${ }^{7}$ However, the direct tasting of God, as Juan de la Cruz emphasizes, is rarely possible. Only the incomparable sweetness of the sporadic encounters can fuel the Amada's search for the one that is almost always hidden, or at least imperceptible to the senses. Consequently, Juan de la Cruz states that it is convenient for the soul to hold onto God as hidden, and to look for him in hidden ways, saying: "Where did you hide, beloved?" (1.9).

Rāsa Lìlā, on the other hand, narrates the amorous activities of Kṛșa with the gopis, young cowmaidens of the village of Vraja. ${ }^{8}$ In the words of Daniel Sheridan, the Bhägavata Purāna-in which the Rāsa Lìlā is includedmarks a truly creative religious moment in which the transcendence and the immanence of God are beheld equally (2). ${ }^{9}$ Within this context, Rāsa Lìlā is considered the sum and substance of bhakti. Generally translated as "devotion," bhakti evokes a mutual relation between the divine and the person where each part enjoys, shares, and loves the other. In his commentary to Rāsa Lìlā, Srīdhara Svāmi describes the bhakta-the one who practices bhakti-as being always satisfied by service at the dust of god's feet, and therefore not bound by desire (10.33.35). However, the most important quality of bhakti is the spontaneous sharing of love; sauhrdyam bhaktim, says Srīdhara, "bhakti is good heart" (10.29.15).

The narration of Rāsa Lìlā fluctuates between the appearances and disappearances of Krșna who constantly leaves the gopis, in the words of Srīdhara, "heated by separation" (10.30.1). Even when in Rāsa Lìlā the gopis are said to have "arrived at the end of their desire" (10.32.13), they are never devoid of the feeling of separation from their bewildering lover. These divine comings and goings are known in the bhakti tradition, and particularly in the context of Rāsa Lìlā, as vipralambha, "love in separation," and sambhoga, "love in union". ${ }^{10}$ Commenting upon the love exchanges between the gopis and Kṛṣna, Rūpa Gosvāmin states: "Love in union does not prevail without love in separation" (Ujjvalanilamanih "Atha śrngāa" 3). Following this principle, the relief of the burning gopis is always at those intervals between the appearance and disappearance of their lover, whom they call a "hard-to-be-with husband" (10.29.10) and a "God difficult to understand" (10.29.31).

In the Cántico, as well as in Rāsa Lìlā, the inquiry that guides the search for the divine is not "Where are you?" but rather "Where have you gone?" It is never a question of existential lack or emptiness of meaning, but a fading from view, a withdrawal. Each in its distinctive mode and direction, both works transit through poetical movements of withdrawal initiated by the withdrawal of the divine himself, followed by the withdrawal of the female beloveds in search for their lover, and eventually arriving at secret places where the narratives slip-an apophatic event that I identify as the withdrawal of the question of location. While these three moments of withdrawal are not consecutive and can hardly be read in isolation, 
focusing on them as textual landmarks makes apparent that the answer to the divine's whereabouts is not to be found at one particular moment in the texts, but rather it is found in the recurring withdrawals of the divine lover, the beloveds, and the question of location. Reflecting upon the location of mystery as a key component of mystical literature, Michael Sells asserts that the mystery is a "referential openness" which can only be glimpsed at-not permanently staredin the interstices of the text, in the tension between the saying and the unsaying (8). ${ }^{11}$ As we will observe in the following pages, each withdrawal-even that of the very question of location-produces a referential openness that continuously propels the search. ${ }^{12}$

As Kṛșa and the Amado withdraw from view, they create the gap of absence that impels the Amada and the gopis to seek out the lover. As the gopis and the Amada search for their lovers, they withdraw from their spaces of identity, and are described as entering into unknown and hidden mental and physical landscapes. In this manner, the texts create the conditions for the encounter between the hidden beloveds with the hidden divine lover. As female beloveds and divine lover unite at secret places, the withdrawal of the question of location takes place, and the divine lover recedes again from view, leaving the beloveds with the "Where?" Those secret spaces, where secret talks are held and secret actions take place, signal the eternal reenactment of the experience of encounter with and departure from the divine lover to which the gopis and the Amada, as well as the reader, are led. I will now discuss selected passages from the Cántico and Rāsa Lìla describing the withdrawal of the divine and the withdrawal of meaning. ${ }^{13}$

\section{The Withdrawal of the Amado and Krșna: Going into Hidden}

Commenting on the first verse of the Cántico, Juan de la Cruz describes three forms of presence in which God exists in every creature: through essence, through grace, and through spiritual affection. Furthermore, he declares that the Amada is claiming for the highest of the three, which is the "affective presence"
(11.4). With this affirmation, Juan de la Cruz links his poetry and theology to Dionysius's description of the act of contemplating the divine not as an exercise of seeing an image, but of inhabiting a place. ${ }^{14}$ Building upon Juan de la Cruz's commentary and emphasizing the Dionysian concept of contemplating as inhabiting, Edith Stein explains these three forms of presence as "three forms of indwelling," and describes the "affective presence" as "the indwelling of mystical love" (175). This ultimate indwelling, as a "being within each other," (169) evokes the image of each part-the divine and the human-creating a space within to contain the other, at the time that he or she is contained within the other. ${ }^{15}$ The goal of the Amada in the Cántico is to arrive at that place of "indwelling of mystical love," where she can inhabit the divine while being inhabited by him, and where she can finally and freely "taste the living God." However, this place of indwelling seems to be found not within the text, but rather in its exterior.

The Cántico begins in media res at a place of absence where the Amada has been left by her Amado after a previous encounter not witnessed by the reader:

Where did you hide, Beloved, and left me moaning?

Like the stag you fled

having wounded me;

I went out running after you, but you were gone. (1)

Baffled by his sudden departure, she wonders about his whereabouts, and her very act of questioning is the only clue the reader has to the fact that he has not remained permanently out of sight, but has shown himself and then gone into hiding. Being a question about location, the first stanza of the Cántico functions as an initial referential openness, drawing the reader's attention to that unknown destination outside the textual corpus where the Amado withdrew, taking with him the place of union. To that location of "indwelling of mystical love" the Amada moves throughout the poem while asking, "Where did you hide?" 
As a referential openness, the function of Where? is to recreate not the state of absence or presence, but the event of revelation. Juan de la Cruz stresses in the commentaries that the object of the Amada's search is none but the "manifestation of the divine essence" (1.3), and her question is not to be directly answered in the linear continuum of the speech, but its answer rests on its own utterance, on the certainty of a previous presence and the expectation of a future return.

In his commentaries, Juan de la Cruz advises the Amada-identified with the human soul-to adopt an attitude of concealment in order to find that one who first concealed himself: "Because the one who is meant to find what is hidden, that much in the hidden and in a hidden manner he must enter, and when he finds it, he is also hidden" (1.9). At the same time, Juan de la Cruz warns that regardless the efforts to hide herself, the Amada will only be able to see the divine as an "imperfect drawing," because "in this life" the real presence cannot be perceived (1.4). Going into hiding within herself, the Amada guarantees the vision of the essence, although "in the other life." Following this thought, we observe that while the place of the theological location of indwelling is the inside of the soul, the poetical location of indwelling is outside the text. As in the other life, the presence of the divine is held in a space suggested by words, but apart from the poem.

On the other side of the comparison, the mode in which Kṛ̦na hides from the gopis is described as antarhita-literally, "placed within." ${ }^{16}$ As used throughout Rāsa Lìlā, antarhita indicates the action of "placing within" performed by the divine and, in resonance with the notion of indwelling in the Cántico, it evokes a secret location that is never totally unveiled. However, antarhita conveys a sense of interiority that contrasts with the exterior location where the Amado hides even before the beginning of the poem.

If one superimposes the narratives of $R \bar{a} s a$ Lìlā and the Cántico as if they were slides on an overhead projector, it becomes obvious that the scenery of the Sanskrit text opens before that of its comparand, and the question for the location of the divine appears later. The narration of Rāsa Lìlā begins by describing how Krșna turned his mind to the enjoyment of love, invoked the power of yogamāya to perform his lìlā, and played his flute (10.29.1-2). ${ }^{17}$ At that sound, the gopis have no choice but to run away from all their prescribed duties and, after a passionate theological argument with the women, he decides to enjoy love with them, but immediately after disappears from their midst, "to calm and favor" the pride they were exhibiting as a result of the satisfaction of their desire (10.29.48). The words used to describe the disappearance of the divine are tatra eva antardhiyata, literally, "right there he placed himself within". 18

In the second chapter of Rāsa Lìlā, antarhita appears again, this time closely related to the term rahas-mostly used with a connotation of mystery, secrecy, mystical knowledge, and also as an erotic secret.

Remembering those secret encounters, the kindling of passion in the heart, the smiling face and the loving looks, and seeing the beauties of your broad chest,

the mind is bewildered,

and we are extremely desirous to be where you are. $(10.31 .17)^{19}$

The word used in the first line of these verses is rahas. Here translated as "secret," it evokes all the gopis cry for: the erotic encounters, the mystical knowledge, the secret of Krșna's love. When the gopis are searching in the forests of Vrindāvan, they find the footprints of Krșna and realize that he has fled with one of them and taken her "to a secret place." Still, the group of gopis is able to speculate on what happens to this gopi thanks to the footprints that reveal clues to their amorous games. Through the metaphorical window opened by the footprints, it becomes clear that this chosen gopi reacts to the lover's special attentions with pride, as the group of gopis had done at the end of the first chapter. She refuses to walk any further and asks Kṛșa, "take me where your mind is" (10.30.37), to which the lover answers with a new withdrawal: 
Kṛșna said to the beloved 'climb to my shoulder,'

then he vanished,

and she became very remorseful. (10.30.38)

Here again, the word used to describe Kṛșna's hiding is antardadhe, a verbal form derived from antardhā. By the action of placing himself within, Kṛșna leaves the chosen gopi outside that secret place (rahas) where they had been sharing love.

Akin to the fleeing of the Amado in the Spanish text, Krșna's placing of himself within creates a referential openness that can only be filled by his return. Departing from its comparand, the referential openness created by the action of antarhita points to the interior of the text, not to its exterior. That this emptiness produced by Kṛṣna's missing kindles the women's desire, Clooney reminds us, is grounded in the fact that "one experiences what does not remain surely present" (Seeing 106). The gopis, as well as the Amada, know that there is one secret place, which is the only possible dwelling where they can experience the deepest kind of love that only their lover can offer. However, their union cannot exist without the gaps of separation, and sharing only occurs at that threshold where Krsna and the Amado, Gods "hard to understand," never remain surely present.

\section{The Withdrawal of the Question for Location}

Immersed in their search for he who first receded from view, the Amada and the gopis arrive at places of encounter with their divine lover. These destinations, so sought after by the female beloveds, are expected to bring the narrative to a completion, closing the referential openness left by the disappearance of the divine and answering the question about his location. However, upon arriving there, the texts become obscure rather than clear, as beloveds and lover engage in secret talks, involving secret meanings that are not to be revealed.

There is more than one location in the Cántico that may answer the "Where?" of the Amado and the longed destination of the Amada, where she finally contemplates her divine lover not by seeing him clearly, but by inhabiting his locus of indwelling. Those places of encounter are not clearly described in the poem, and the language used to refer to them carries strong connotations of secrecy. Among them are the water of a fountain, where the lover and the beloved indwell in each other's eyes, an orchard or garden, an apple tree under which they sit, a flowered bed, an inner wine cellar, and caverns. ${ }^{20}$

Amidst these indwelling loci, the interior wine cellar is where the highest form of "indwelling of mystical love" takes place:

In the inner cellar

of my Beloved I drank, and when I came out

to all these valleys

I did not know a thing,

and I lost the flock that I was following.

There he gave me his breast,

there he taught me a very savory science, and I gave myself to him indeed,

without leaving a thing;

there I promised him to be his wife. (26-27)

While the mutual giving described in these verses fulfills the Amada's desires, the repetition of the adverb alli ("there") leads to uncertainty. The entrance into that "there," so intimately known to the Amada, is never to be opened to the reader. Before commenting upon this verse Juan de la Cruz asks-in a singular instance throughout all his commentary-for the Holy Spirit to take his hand and to move his pen (26.3). The "interior wine cellar," he says, represents the deepest state of love between the Amado and the Amada, and what God communicates there to the soul "cannot be said, just as about God himself nothing can be said; because God himself is what has been communicated" (26.4). The referential openness in this stanza is marked grammatically by the repetition of the relative alli, pointing at the always-receding location of the Amado. Indwelling with him, the Amada has reached the outer-though hidden-place where her lover had escaped. At this point, both the poem and the commentary fold onto themselves, covering the entrance into that locus where the sharing of divine love remains 
sealed. The question of "Where?" then, renders itself unanswerable in the continuum of the narrative until the Amada unexpectedly arises from the wine cellars asking again for her lost lover.

While the Amada enters and leaves the interior wine cellars, her comparands, the gopis, arrive at the shore of Yamuna River, where Krṣna manifests among them (10.32.2). When the lover appears, he graciously shares love with his beloveds, and rests in a seat arranged by their upper garments, smeared with the kumkum from their breasts (10.32.13). Then it is said that the women "went to the end of their desire" (10.32.13), but still, they take a step back from the intensity of emotion to ask their lover about the nature of his love:

Some love those who love them, others do the opposite, and even others do not love anyone.

Tell us properly. (10.32.16)

In his commentaries to this stanza, Srīdhara affirms that the gopis "were asking for a secret meaning as if it were something from the world." The hidden answer that the gopis want to approach is the means of bhakti, the particular ways in which Kṛșna shares love with them. His answer begins by recounting the different kinds of human attitudes toward love: first, those who love like parents; second, those who love only when they are loved; third, those who do not love anyone because they cannot see beyond themselves; and finally, those who do not love anyone because all their desires are satisfied (32. 17-20). After this detailed classification, Krṣna finally addresses the hidden question of the women:

Because all of you, women, abandoned the world, the Veda, and your kin for my sake,

you really love me.

I became invisible, loving you from a distance.

Therefore, beloved ones,

do not resort to anger toward the very thing you love. (10.32.21)
Srīdhara's grammatical illustration to this verse sheds light upon its theology. ${ }^{21} \mathrm{He}$ explains tirohitam (imperceptible or invisible) as antardhānena, declined in the instrumental case: by the act of antardhā or placing within. With this, Srīdhara links Kṛṣna's answer to his two previous disappearances--that from the group of gopis (10.29.48) and that from the single gopi (10.30.38). In the three instances, the term used to describe his mode of hiding is antarhita, signaling a movement of the divine to an unknown interior location. Srïdhara points out that by his antarhita, Kṛșna was tirohitam (imperceptibly) sharing love with the gopisbhajatā. Kṛșna's answers to the gopis' secret question could also be put as, "I share love with you invisibly." The means for the bhakti between Krșna and the gopis is precisely his placing himself within (tirohitam as antardhānena).

\section{Locating the Divine in Comparison}

The Amado of the Cantico is compared with a stag, "like the stag you fled," and in his commentaries Juan de la Cruz explains that this simile results not only from him being strange and solitary, but also "for his quickness to hide and to show" (1.15). The metaphor of the fleeing stag can be easily extended to Krșna, the "hard-to-be-with husband" known to his beloveds for this hiding and tricking fashions. Searching for such fleeing Gods, the Cántico and Rāsa Lìlā perform a constant movement towards the secret locations of indwelling and antardha. Rather than stating where the divine is, these texts move toward it, and their answer to the question of the divine location rests upon their very search.

Accordingly, the comparison of these texts cannot aim to arrive at a clearly defined method for asking or answering where is the divine located. The comparativist rather stays close to the poetical movements of withdrawals performed by the divine, the beloveds, and the question of location. Images that move, Elaine Scarry reminds us, are also easily imagined (90). From all the movements performed by the Cántico and Rāsa Lìlā, the easiest to imagine are those of the gopis running with their earrings "trembling by the speed" (10.29.4.) at 
the sound of Krṣna's flute, and the Amada flying over mountains and valleys towards the unknown destination of her Amado (3). Being the agents of the search, the gopis and the Amada hold the eye of the reader, taking her into their transit to reach the always-receding divine lover.

By way of concluding, I want to look briefly at the search for God from the perspective of the movements of withdrawals performed by the Amada and the gopis, focusing on the directions in which they move. We have already observed that antarhita refers to Kṛșna's action of hiding in an interior and secret location. On the other hand, the notion of indwelling in the Cántico is theologically defined by Stein as a "being within each other" (175). Both indwelling and antarhita bestow the texts with a sense of interiority and exteriority. In the exteriority God is perceptible while in the interiority he hides and attracts the beloveds.

The first "Where?" of the Cántico points to the withdrawal of the divine into a location outside the textual corpus, and towards this outer abode we see the Amada running, overflying the landscape. In contrast, Kṛșna is said to have placed himself into an interior location, and the gopis, imitating the lover's direction, get lost in the midst of the woods. While the Amada "crosses mounts and frontiers" (3) without caring for the details of the scenery, the gopis talk to the trees and leaves, and scrutinize through lover's footprints the simultaneous narrative of his encounter with one. The Amada seems bound to the outer space, to that "Where?" outside the text where her lover withdrew. The gopis look to share love with Kṛșna in the innermost of the forest, of the night, of Krṣna's lila

The Amada and the gopis seem to move in opposite directions towards the location of the divine. However, withdrawing to the exteriority of the text or to its interior, the locations of the Amado and Kṛnna share two notable features: they are described as secret, and they are to be found between the divines' absences and presences. When the Amada arrives at the inner wine cellar and indwells with her lover, the outer directionality of the poem reverses into a sense of hiddenness and secrecy. The only action described by the poetry is that she drank from such an unnamable and delicious drink that Juan de la Cruz finds impossible to explain, even in the more distant theological mood of the commentary.

On the other side, although Krșna explains the means of his bhakti telling the gopis that he graces them by his own withdrawal, the meaning of Rāsa Lìlā is never revealed beyond pointing to that hidden location where he places himself-antarhita. The only possible glimpse into the secret kept within such loci opens at the intermittencies of the divines' showing and hiding. Hiding, God creates the referential openness that propitiates the search, and it is precisely through this search that the Amado and Krșna will eventually-if always partially-manifest. Directionality, an aspect that would hardly arise outside the comparative frame, opens the way to further inquiries on the question of location and space in mystical literature, and to theological concerns about the interiority and the exteriority of textual representations of the search for the divine.

As for the Cántico and Rāsa Lìlā, the revelation of comparison dwells not in finding an answer to the question of location, but in inhabiting the question.

\section{Works Cited}

Bhāgavata Purāna with the Commentary of Srìdhara Svāmi. Delhi: Motilal Banarsidass, 1999.

Clooney, Francis. Beyond Compare: St. Francis de Sales and Śrì Vedānta Deśika on Loving Surrender to God. Washington: Georgetown UP, 2008.

---. Seeing Through Texts: Doing Theology among the Śrivaisnavas of South India. New York: State U of New York P, 1996.

Cruz, Juan de la. Cántico espiritual. Obra Completa. Ed. Luce López Baralt and Eulogio Pacho. Madrid: Alianza Editorial, 2003.

Damrosch, David. What is World Literature? Princeton, NJ: Princeton UP, 2003.

Gosvāmin, Rūpa. Ujjvalanilamanih. India: Gaudiya Vedānta Prakāśakan, 2006.

---. The Bhaktirasāmrtasindhu of Rūpa Gosvāmin. Trans. David L Haberman. New Delhi: 
Indira Gandhi National Centre for the Arts and Motilal Banarsidass, 2002. McGinn, Bernard. The Foundations of Mysticism. New York: Crossroads, 1999.

Pseudo-Dionysius. "The Mystical Theology." The Complete Works. Trans. Colm Luibheid. New York: Paulist, 1987.

Scarry, Elaine. Dreaming by the Book. New York: Farrar, 1999.

Sells, Michael A. Mystical Languages of Unsaying. Chicago: The U of Chicago P, 1994.

Sheridan, Daniel P. The Advaitic Theism of the Bhāgavata Purāna. New Delhi: Motilal

Banarsidass, 1986.

Stein, Edith. The Science of the Cross. Trans. Josephine Koeppel. Washington, D.C: Institute of Carmelite Studies, 2002.

\section{Notes}

${ }^{1}$ Unless otherwise noted, all the translations from Spanish and Sanskrit into English of the texts and the commentaries are mine. For certain passages I have consulted the translation of the Cántico into Englishby Colin Thompson, which appears in the "Appendix" to The Poet and the Mystic (1976), and for Rāsa Lìlā I have consulted the translation of Edwin Bryant in Krishna: The Beautiful Legend of God (2003). For the commentary of Srīdhara Svāmi I have not consulted any translation. I am thankful to Meenal Kulkarni for her guidance reading Rāsa Lìla and the commentary of Srïdhara, as well as any other Sanskrit text cited here. I am grateful to Shrināth Shastriji, founder of a Bhāgavata Vidyālaya in Vrindāvan, for patiently answering my questions about the grammatical and theological nuances of Rāsa Lìla and the commentary of Srīdhara. I also thank the reviewers of the Journal of Hindu Christian Studies for their corrections and comments, and Professor Deven Patel, from the University of Pennsylvania, for last minute consultations. In some cases, I have decided to render the translations as exercises in interpretation.

${ }^{2}$ I am using Bernard McGinn's definition of the mystical as "not a particular kind of experience but the knowledge (or better, 'superknowledge') that deals with the mystery of God in himself" (171).
${ }^{3}$ In the field of comparative theology, this study is informed by the work of Francis Clooney, Daniel Sheridan and Michelle VossRoberts, who have approached from distinct perspectives the comparison of Hindu and Christian mystical authors. In particular this paper owes to conversations with Francis Clooney, and to his upcoming book His Hiding Place Is Darkness: An Exercise in Interreligious Theopoetics. Stanford University Press, 2013.

${ }^{4}$ My doctoral dissertation, "Absence, Presence and Divine Vision" (Emory U. 2011) is a comparison of the Cántico espiritual with Rāsa Lìlā, along with the commentary that San Juan de la Cruz wrote for his own poem, and the commentary of Srīdhara Svāmi on Rāsa Lìlā. Here, for the first time, I focus on the topic of God's location.

${ }^{5}$ Beyond Compare (2009).

${ }^{6}$ The Cántico espiritual is the first of Juan de la Cruz's three main poetic compositions to which he added commentaries, turning them into theological treatises. The other two are Noche oscura (Dark Night of the Soul) and Llama de amor viva (Living Flame of Love). He wrote four commentaries: one to the Cántico, two to the Noche oscura (Subida al Monte Carmelo and Noche oscura) and one on the Llama de amor viva. Although the Dark Night of the Soul is probably the best known and most studied of Juan de la Cruz's works among English speakers, his entire literary corpus is filled with images of the absence of God that is nonetheless present.

${ }^{7}$ Gustar a Dios vivo (To taste the living God) are the words used by Juan de la Cruz in his commentary to the Living Flame of Love (1.6). With this, he was evoking Origen's Commentary to the Song of Songs, and Dionysius the Areopagite's interpretations of Origen's notion of God as eros.

${ }^{8}$ Rāsa Lìlā is composed by chapters twenty-nine to thirty-three of the Canto $X$ of Bhägavata Purāna.

${ }^{9}$ Although I am not focusing on this question, there is a suggested resonance between Juan de la Cruz's image of tasting the living God with the Hindu aesthetical notion of Rasa, and particularly with the aesthetical-theological concept of Bhakti Rasa as developed in the sixteen century by Rūpa Gosvāmin and Jivva Gosvāmin, founders of the Gaudiya Vaișnava 
School. They defined Bhakti Rasa as "pure serving with the senses to the Lord of Senses" (The Bhaktirasāmrtasindhu 1.1.12), and conceived the love for Krșna (Krșnaratih) as the foundational emotion of Bhakti Rasa (The Bhaktirasāmrtasindhu 2.1.5). In the same fashion, the notion of acintyabhedābheda or "unthinkable difference in identity," also developed by the Gaudiya Vaișnava School, holds suggestive comparative resonances with Juan de la Cruz's notion of "indwelling" as called by Edith Stein. Such comparison would require a different approach from the present one, where I am reading Rāsa Lìlā with the help of Srīdhara Svāmi's commentary.

${ }^{10}$ The concepts of vipralambha and sambhoga were first stated by Bhārata in his dramatic treatise Natyaśastra. Bhārata explains that the two manifestations of erotic love are joined enjoyment (sambhoga), usually translated as union, and separation or disunion (vipralambha).

11 While Sells explains the "referential openness" in the context of apophasis, for the purpose of this paper I want to focus on the movements of withdrawal represented in the Cántico and Rāsa Lìlā, which poetically precede the occurrence of the "referential openness". I am also following Sells by using the "referential openness" as means of conversation between two different traditions, as proposes in Mystical Languages of the Unsaying (8).

${ }^{12}$ Although I am not keeping that perspective in the present study, it would be possible to compare the dynamics of absence and presence within the context of the performative practices involving these texts. The Cántico and its commentary are an important part of the spiritual teachings and practices for nuns and priests of the Discalced Carmelite order, and for other contemplative orders. Rāsa Lìlā remains one of the most popular, widely performed, and promoted Krishna-related texts in India.

${ }^{13}$ In the conclusions I will draw upon the withdrawal of the female characters.

${ }^{14}$ In the treatise "Mystical Theology" Dionysius writes: "And yet he does not meet God himself, but contemplates, not him who is invisible, but rather where he dwells" (137).

${ }^{15}$ The complete passage by Stein reads: "To be an indwelling, both sides must have an inner being, that is, a being that contains itself interiorly and can receive another being within itself, so that without the accepted and the accepting beings ceasing to be independent, a unity of being comes into existence...This alone is authentic indwelling" (175).

${ }^{16}$ Antarhita is a compound formed by the prefix antar, "within," and the past passive participle hita, from the verbal root dhā, to place. Commonly translated as "disappeared," here I am stressing the literal meaning of the term and the sense of interiority (antar) that it carries.

${ }^{17}$ The notions of yogamāyā (illusion of union) and lìla (divine play) frame poetically and theologically the antarhita of Krșna. From the moment that the God plays his flute, every action can be said to happen-at the narrative level-but at the same time to be only the result of the illusion of union that fulfills Krșna's desire to enjoy love with the gopis, and also satisfies the gopis's desire for him. The divine passes as demiurge of his own text, and the image of Kṛṣna hidden within- antarhita comes to be the figuration of Kṛṣna's will to play, lìlā, under the veil of yogamāy $\bar{a}$.

${ }^{18}$ Antaradhiyata is a perfect form derived from the prefix antar, "inside," and the verbal root $d h \bar{a}$, "to place". This is the first instance when the term is used in Rāsa Lìlā to describe the mode of Krșna's disappearance.

${ }^{19}$ I thank Deven Patel for his help in the translation of this verse and the verse quoted on page 14 .

${ }^{20}$ Most of these locations are directly taken from the Song of Songs.

${ }^{21}$ The Sanskrit verse reads:

evam madarthojjitalokavedasvānām hi vo mayyanuvrttaye'balāh/

mayā parokșam bhajatā tirohitam mā'suyitum mārhatha tat priyam priyāh//

There are different interpretations of this verse, particularly of the phrase mayyanuvrttaye. While the more literal meaning of anuvrttaye is "following," it includes the notions of service, devotion, and love. I am as well highlighting the meaning of bhaj as a mutual sharing of love. 